\author{
WERBALIZACJA EMOCJI \\ W TEKSTACH ROSYJSKIEJ KRYTYKI MUZYCZNEJ \\ VERBALIZATION OF EMOTIONS \\ IN RUSSIAN CRITICAL TEXTS ON MUSIC
}

\title{
MARIA DZIENISIEWICZ
}

\begin{abstract}
AвSTRACT. The paper is an attempt to present the ways of verbalization of emotions in Russian critical texts. The material shows examples of verbalization in two aspects of analysis: in first part the material has been divided into five groups and focused on the grammatical characteristics of the examples, in second part the author of the article attempts to compare the descriptions of emotions written in music score with examples of verbalization used in critical texts on music. The studied material shows a variety of ways of verbalization of emotions in analyzed texts.
\end{abstract}

Keywords: verbalization, emotions, classical music, Russian, musical criticism

Maria Dzienisiewicz, Uniwersytet im. Adama Mickiewicza w Poznaniu, Poznań - Polska, maria.z.wojcik@gmail.com

ORCID ID: 0000-0001-6140-6889

\section{Wprowadzenie}

„Istnieją dźwięki, które wyrażają radość, inne smutek i przygnębienie, jeszcze inne czułość i miłość, a słuchając ich w sposób naturalny jednoczymy się z tymi, którzy się radują albo cierpią" - tak w 1775 roku w pracy An Essay on Musical Expression pisał Charles Avison [Avison 1775: 3-4]. Angielski kompozytor i estetyk nie był pierwszym, który podkreślał emotywne znaczenie muzyki. Już pitagorejczycy zajmowali się estetyką muzyki i jej wpływem na nastrój człowieka. Damon określał ją jako prawdziwy i właściwy środek kształtowania duszy, Platon wskazywał na ambiwalentny charakter muzyki, opisując ją z jednej strony poprzez odwołanie się do sfery ratio, z drugiej do sfery emotum [Biłas-Pleszak 2005: 90-92], zaś Arystoteles poruszał kwestię tonacji, stwierdzając, że „niektóre melodie wprawiają w nastrój smutny i przygnębiony (skala miksolidyjska), inne budzą nastrój wesoły, jeszcze zaś inne wprawiają w nastrój pośredni i poważny (skala dorycka), podczas, gdy skala frygijska budzi zachwyt" [Fubini 1997: 56]. Święty Bazyli w swej homilii o I Psalmie stwierdza między innymi, że „[...] psalm daje spokój duszy, jest 
panem pokoju, łagodzi nieład i rozterkę myśli, albowiem uspokaja namiętności duszy i miarkuje jej rozpasanie" [cyt. za Fubini 1997: 70]. Znacznie później zależności pomiędzy muzyczną skalą a uczuciami opisał w De Musicae Laudibus Oratio seu adhortatio polski kompozytor oraz teoretyk muzyki Jerzy Liban z Legnicy. Poniżej przytaczam fragment tego dzieła przetłumaczony na język polski [Mika 2007: 99-100]. Ukazuje on przykład werbalizacji (rozumianej jako przedstawienie lub wyrażenie czegoś za pomocą słów) emocji towarzyszących odbiorcy muzyki:

[...] pierwszy ton z autentycznych porusza flegmę i budzi ze snu. Jest stosowany dla ludzi utalentowanych i sławnych. [...] Jak bowiem słońce wysusza wilgoć i rozprasza ciemności nocy, tak ton pierwszy szybko usuwa lenistwo, smutek, senne odrętwienie [...]. Najodpowiedniejsze są dla tego tonu słowa żartobliwe, miłe, dowcipne ${ }^{1}$.

Drugi ton [...] porównywany jest do księżyca i jemu podporządkowany, ponieważ tak jak wilgotny księżyc znajduje się niżej niż inne planety, tak ten ton, smutny i płaczliwy, jest niższy od wszystkich innych tonów. W szczególności jest łagodny i proszący. A ponieważ prośbie towarzyszy zazwyczaj pokora, a często i płacz, przeto należy przydzielić temu tonowi słowa skłaniające do skruchy i łez.

Trzeci ton [...] przydzielany bywa Marsowi [...], ponieważ jest na wskroś surowy i posiada zdolność pobudzania jak Mars. [...] słusznie przeto powinno się dla niego dobierać słowa ostre albo opowiadające o minionych bitwach.

Czwarty ton [...] swym brzmieniem uspokaja. Merkury bowiem rządzi tym tonem. $\mathrm{Z}$ tej racji właściwy jest pochlebcom, którzy zarówno dobrych, jak i złych [...] chwalą dla swoich korzyści. Tak samo ten ton łatwo dostosowuje się zarówno do płaczu, jak i do radości [...] słusznie przeto należy przydzielać mu słowa oznaczające pochlebstwa, oszustwa i oszczerstwa.

Piąty ton włada krwią i przyrównywany jest do Jowisza, pod którego wpływem ludzie okrutni stają się życzliwi, łagodni i mili, ponieważ on zawsze lubi radość i wesołość. $Z$ tej racji słusznie powiada święty Augustyn, że ton ten [...] rozwesela smutnych i zatrwożonych, pociesza upadłych i zrozpaczonych [...]. Należy więc dobierać do tego tonu słowa wyrażające radość i wesołość lub opowiadające o jakimś zwycięstwie. Szósty ton [...] przydzielony jest Wenerze, pod której wpływem ludzie stają się pobożni i skorzy do łez. Tak i ten ton skłania czasem do bogobojnych łez, pochodzących z wiary i radości. [...] najważniejsze są dla niego słowa pobożne i święte, skłaniające do łez spowodowanych pobożnością, współczuciem i radością duchową.

Siódmy ton brzmieniem swym porusza czarną żółć. Albowiem ludzi, którzy pod wpływem Saturna [...] stają się smutni, opieszali, powolni i ponurzy, ton ten swoją harmonią nadzwyczaj pobudza i doprowadza do pewnej gwałtowności. [...] przeto bardzo odpowiednie są dla niego słowa twarde i surowe, a także oznaczające pewną gwałtowność.

Ósmy ton [...] smutnych i powolnych doprowadza do umiarkowanej wesołości. [...] Niektórzy mówią, że wyraża także chwałę i dlatego przez świętego Ambrożego określany jest jako przyjemny i obyczajny. Odpowiada najbardziej ludziom roztropnym, którzy wnikliwym umysłem badają to, co najgłębiej ukryte [...].

\footnotetext{
${ }^{1}$ Pogrubione fragmenty w obrębie cytatu - M. D.
} 
W epoce baroku powszechna staje się praktyka podkreślania emocji (afektów) poprzez charakterystyczne muzyczne motywy. Teoria afektów (Affektenlehre) wskazywała na zdolność muzyki do wyrażania stanów uczuciowych, a samą muzykę nazywano mową afektów. Jezuita Athanasius Kircher jako pierwszy skodyfikował Affektenlehre w Musurgia universalis sive Ars magna consoni et dissoni (1650), systematyzując afekty jako wynik różnego rodzaju muzyki [Fubini 1997: 168]. Albert Schweitzer, opisując język muzyczny Jana Sebastiana Bacha, ukazuje na szereg motywów nazywających stany emocjonalne, realizowanych poprzez odpowiednie środki wykonawcze. Motyw błogiego spokoju, inaczej nazywany szczęsnym uwielbieniem, realizowany jest poprzez charakterystyczną formułę rytmiczną; radość jest, zdaniem Schweitzera, wyrażana bądź jako gamowy szybki przebieg wartości ósemkowych lub szesnastkowych, bądź za pomocą specjalnej formuły rytmicznej. Omawiając język muzyczny kantat Jana Sebastiana Bacha, Schweitzer wymienia także motywy zmęczenia i niemocy (wyrażane synkopami), rytmy szczęśliwości, motywy przerażenia (powtarzane motywy szesnastkowe, często w postaci akordów), motywy bólu (chromatyczny postęp dźwięków) [Schweitzer 1972: 387-423].

Systematyzacja oznaczeń dotyczących uczuć w muzyce klasycznej była procesem, którego początki należy wiązać z zanikiem średniowiecznej anonimowości twórców muzyki. Za wprowadzenie określeń w języku włoskim nie odpowiada konkretny autor, dlatego trudno podać dokładną datę pierwszego umieszczenia w tekście nutowym adnotacji dotyczących charakteru bądź nastroju utworu muzycznego. Za twórcę pierwszego słowniczka terminów muzycznych Terminorum musicae diffinitorium uważany jest Johannes Tinctoris, teoretyk działający w drugiej połowie XV w. [Fubini 1997: 109-110]. Słowniczek ten, definiujący pojęcia harmonii, konsonansu, kompozytora, nie zawiera jeszcze włoskich oznaczeń wykonawczych nazywających emocje i uczucia towarzyszące wykonawstwu muzyki. W dziele Complexus effectuum musices Tinctoris idzie o krok dalej - wymienia dwadzieścia efektów, jakie muzyka wywiera jego zdaniem na słuchaczu, innymi słowy - będących efektem jej emocjonalnego oddziaływania. Oto fragment omawianego dzieła:

Boga radować,

Boga chwalić,

Radości zbawionych zwiększać,

[...] Smutek rozpraszać,

Zatwardziałość serca zmiękczać,

[...] Dusze do walki podniecać,

Miłość podsycać [...]

Zagadnienie werbalizacji afektów zajmowało później i innych teoretyków, m.in. Jean-Baptiste'a Dubosa, filozofów (Kartezjusz, Leibniz), natomiast 
w Dictionnaire de la musique Jean-Jacquesa Rousseau znajdziemy już (co prawda nieliczne) powszechnie dziś stosowane oznaczenia emocji: affettuoso, amoroso, barbare, cantabile, dolce, grave, pathetique, sensibilite, tendrement [Rousseau 1780-1789]. We współczesnych słownikach terminologii muzycznej notuje się znacznie więcej oznaczeń oddających szerokie spektrum ludzkich uczuć, takich jak: affabile (pogodnie, z wdziękiem), brio (z ogniem, z życiem), dolce (słodko, delikatnie), dolendo (żałośnie, boleśnie), feroce (dziko, gwałtownie), gioioso (wesoło), impetuoso (gwałtownie), lugubre (ponuro, żałośnie), maestoso (uroczyście), piangendo (płaczliwie, żałośnie), risoluto (stanowczo), soave (łagodnie), tranquillo (spokojnie) [Reiss, Śledziński 1960]. Określenia te, będące formą werbalizacji emocji, posłużą jako punkt wyjścia dla drugiej części analizy porównawczej materiału niniejszej pracy.

Należy tutaj zaznaczyć, że pojęcia emocja i uczucie traktujemy synonimicznie. Stanowiska badaczy są jednak w tej kwestii podzielone. Stanisław Grabias, na przykład, stwierdza, że „emocja to typ ekspresji, polegający na uzewnętrznianiu się uczuć, zaś ekspresja językowa to proces ujawniania się nadawcy w wypowiedziach" [Grabias 1997: 292]. Iwona Nowakowska-Kempna dokonuje z kolei rozróżnienia między uczuciami o charakterze zdarzeniowym (emocje podstawowe i krótkotrwałe, inaczej afekty) oraz uczuciami-postawami emocjonalnymi (emocje bardziej złożone i długotrwałe) [Nowakowska-Kempna 1995: 120-122].

Z perspektywy językoznawczej opisanie oraz kategoryzacja stanów emocjonalnych nie jest zadaniem łatwym. Istnieją jednakże badacze, w których kręgu zainteresowań znajdują się związki emocji ze słowem [Иорданская 1970; Wierzbicka 1999; Шаховский 2008; Бразговская 2014 i in.], pojawiają się nowe kierunki w nauce (lingwistyka emocji, lingwokulturologia emocji, lingwistyka kognitywna), a samych badaczy emocji określa się mianem emotiologów [Шаховский 2008]. W różny sposób rozumiane są emocje podstawowe. Lidia Nikołajewna Iordanskaja, powołując się na prace Kartezjusza oraz Spinozy, podstawowymi nazywa uczucia: radości, smutku, gniewu, nadziei, strachu i zdziwienia [za Borek 1999: 10], jednakże inni badacze, jak Silvan Solomon Tomkins, są skłonni zaliczyć do tej grupy również inne emocje: $z a-$ interesowanie, zadowolenie, zachwyt, zdziwienie, zaskoczenie, wstrzas, przykrość, udręka, wstyd, poniżenie, strach, przerażenie, potępienie, wstręt, gniew, wściekłość [za Reykowski 1992: 14]. Dotychczas podejmowano różne próby klasyfikacji emocji. Część badaczy dzieli emocje na pierwotne i wtórne [Reykowski 1992: 14], inni (Iordanskaja) na emocje pozytywne i negatywne - положительное и отрицательное состояние, oraz aktywne i pasywne - активное и пассивное состояние [za Borek 1999: 10]. Typologii stanów emocjonalnych podjęła się także Urszula Jęczeń [Jęczeń 2008: 250-251]. Podział ten dotyczy nie emocji odczuwanych przez wykonawców, twórców, bądź odbiorców muzyki kla- 
sycznej, a emocji w ogóle. Badaczka wskazuje, że dokonujemy werbalizacji stanów emocjonalnych, wykorzystując zawarte w języku: 1) rzeczownikowe nazwy uczuć (np. smutek, wstręt), 2) czasownikowe nazwy uczuć (np. cieszyć się, bać się), 3) nazwy wielowyrazowe (np. radość z cudzego nieszczesścia, wyrzuty sumienia), 4) frazeologizmy (np. być w siódmym niebie), 5) frazemy (np. niech szlag trafi), 6) konstrukcje peryfrastyczne (np. uczucie czci), 7) wykrzykniki jako czysty wyraz emocji (np. Oj, nieładnie!), 8) ekspresywne konstrukcje słowotwórcze (np. podlizywacz, naciagacz, siostrunia), 9) emotywność wprowadzaną $\mathrm{w}$ sposób niejawny jako implikatura (np. Lepiej będzie, jeśli skończymy tę rozmowę), 10) powtórzenia wyrazów (np. A idźże, idźże ty!), 11) afektonimy świadczące o zażyłości (np. promyczku, kotku, najdroższy), 12) odpowiednie środki składniowe, wśród nich pytania retoryczne, powtórzenia. Niemniej na powyższej typologii (nieznacznie zmodyfikowanej) oparto pierwszą część analizy materiału badawczego niniejszej pracy.

\section{Analiza materiału badawczego}

W niniejszym artykule podjęto próbę usystematyzowania określeń nazywających stany emocjonalne wykonawców muzyki klasycznej. Jako materiał badawczy posłużyło 200 tekstów krytyki muzycznej, zdeponowanych w korpusie musiccritics.ru. Korpus ten, zgromadzony przez rosyjskiego krytyka muzycznego Piotra Pospiełowa i będący jednocześnie archiwum tekstów o tematyce muzycznej, zawiera publikacje z lat 1992-2017, opisujące koncerty, festiwale, recitale, premiery oraz inne znaczące wydarzenia w świecie muzyki klasycznej i teatru. Teksty stanowiące przedmiot zainteresowania w niniejszej pracy opisują wykonania solistów-instrumentalistów (Jewgienija Kissina, Gidona Kremera, Natalii Gutman, Eliso Wirsaladze, Grigorija Sokołowa, Hélène Grimaud, Jurija Baszmieta, Michaiła Pletniowa, Aleksandra Kniaziewa, Frederika Kempfa, Władimira Aszkenazi, Aleksandra Toradze). Analizie poddano teksty krytyczne odnoszące się do muzyki instrumentalnej wykonywanej solo (nie uwzględniono muzyki orkiestrowej, kameralnej, wokalnej, wokalno-instrumentalnej). Na ich podstawie wyekscerpowano manualnie 150 jednostek leksykalnych, które następnie podzielono na kategorie gramatyczno-leksykalne.

\subsection{Podział gramatyczno-leksykalny}

Na potrzeby niniejszego opracowania zaczerpnięte z materiału badawczego określenia uczuć zostały pogrupowane według ich przynależności do części mowy. Podział ten częściowo opiera się na typologii zaproponowanej przez Jęczeń, jednakże na potrzeby niniejszego opracowania została ona zmodyfikowana i utworzono następujące kategorie: 


\section{a) rzeczownikowe nazwy uczuć:}

беспокойство, благодушие, благородство, боль, восторг, величественность, взволнованность, горечь, драматизм, жестокость, жизненность, истеричность, мужество, меланхолия, мрачность, мягкость, нега, нежность, неистовство, невозмутимость, отчаяние, одержимость, одиночество, подвижничество, равнодушие, радость, растерянность, сдержанность, серьёзность, страстность, страсть, строгость, тоска, тревога, трагизм, убедительность, удовольствие, фрронда, холодность, храбрость, иеломудрие, честность, чувственность;

\section{b) przymiotnikowe nazwy uczuć:}

агрессивный, благостный, бескомпромиссный, бойкий, бурный, вдохновенный, веселый, взволнованный, возвышенный, восторженный, глубокий, демонический, диковатый, драматичный, задумчивый, миричный, нежный, ностальгический, отчаянный, печальный, порывистый, радостный, раздумчивый, рассудочный, скептичный, серьезный, спокойный, слезливый, скорбной, страстный, строгий, трагичный, торжественный, трогательный, трепетный, умиротворенный, холодный, чувственный. Wśród przymiotnikowych nazw uczuć zwracają uwagę przykłady użycia krótkiej formy: ироничен, капризен, печален, сентиментален, страшен, трагичен, убедителен;

\section{c) przysłówkowe nazwy uczuć:}

„аппасионатно”, бодро, благородно, возвышенно, дружелюбно, задумчиво, заманчиво, захватывающе, меланхолично, мужественно, настойчиво, оптимистично, спокойно, созеризательно, сдержанно, тепло, убежденно, упрямо, убедительно, умиротворенно;

\section{d) czasownikowe nazwy uczuć:}

буйствовать, болевозбуздающий, воодушевлять, отчаявшийся, печаляться, сомневающийся, торжествующий, удивлять;

\section{e) wielowyrazowe nazwy uczuć, utworzone z połączenia wyżej wymie- nionych,}

- przymiotnikowo-imienne (adj. + nom.):

напряженный рахманиновский пафос, волевой напор, романтическая эмоция, угрюмая гроза, напряженный пафос, гордая рысь финала, ицирковое восхищение, глубинная меланхолия, легкая обескураженность, могучий всхлип, тонкие чувства, печальные выводы, нервно-взвинченная агрессия, мрачная тоска, внутренний неуют, скрытая афрфектация, экзальтированная динамика, противоречивые чувства, эмоциональная корректность, эмоциональная броскость, злая ирония, эмоциональный нажим, щедрая отсебятина, радостное чувство, нежная тонкость, угрюмая печаль, безмерная радость, глубокая пе- 
чаль, напускной оптимизм, болезненный оптимизм, печальный контроль (за эмоциями);

- imienno-imienne (nom. + nom.): чувство усталости, чувство опустошенности, ощущение одиночества

- przysłówkowo-przymiotnikowe (adv. + adj.): сдержанно драматичный

- czasownikowo-imienne (verb. + nom.): ищущии успокоения

- przysłówkowo-czasownikowe (adv. + verb.): эмоционально зажечь

- przysłówkowo-przysłówkowe (adv. + adv.): пронзительно грустно

- przymiotnikowo-przymiotnikowe (adj. + adj.): экзальтированно-романтичный.

Najliczniejszą grupę słów nazywających uczucia i emocje towarzyszące wykonawstwu muzyki klasycznej przedstawiają przymiotnikowe nazwy uczuć (45 jednostek). Niewiele mniej licznie prezentuje się grupa rzeczowników (43 jednostki). Wśród nazw wielowyrazowych najbardziej reprezentatywne są połączenia przymiotnikowo-rzeczownikowe (31 jednostek), poza tym odnaleziono trzy przykłady połączeń imienno-imiennych, zaś pozostałe typy (przysłówkowo-przymiotnikowe, czasownikowo-imienne, przysłówkowo-czasownikowe, przysłówkowo-przysłówkowe oraz przymiotnikowo-przymiotnikowe) są reprezentowane przez pojedyncze przykłady. Werbalizację uczuć przy pomocy przysłówków zaobserwowano w 20 przypadkach, natomiast jednostki czasownikowe odnotowano w liczbie ośmiu.

Jak już wspominano, niektórzy badacze [Borek 1999: 10] proponują podział emotywów na posiadające zabarwienie pozytywne i posiadające zabarwienie negatywne. Podział ten jednak, zastosowany dla izolowanych jednostek, wydaje się nieprecyzyjny, ponieważ potrzeba szerszego kontekstu, by dane uczucie określić jako pozytywne bądź negatywne (por. radość $\mathrm{z}$ urodzin dziecka a radość z cudzego nieszczęścia; mitość odwzajemniona a miłość bez wzajemności²).

\subsection{Porównanie tekstu nutowego $\mathrm{z}$ tekstem recenzji}

Interesujące może okazać się zbadanie oraz porównanie, w jakim stopniu środki wyrazowe używane przez krytyków muzycznych pokrywają się z użytymi w tekście nutowym oznaczeniami nazywającymi emocje. Spośród tekstów poddanych analizie jedynie w poniższych przykładach możliwe było dokładne zidentyfikowanie utworu muzycznego, o jakim była mowa w recenzji, bądź jego części (jeśli, jak w przypadku sonaty czy koncertu, opisywano utwór wieloczęściowy):

2 Por. miłość frustracyjną jako jedną z najbardziej przykrych emocji negatywnych [Borek 1999: 10]. 
1. Franciszek Liszt Danse macabre (wykonanie Michaił Pletniow)

- w tekście nutowym znajdują się następujące oznaczenia (w nawiasach podano ekwiwalenty rosyjskie określeń włoskich zaczerpnięte ze słownika terminologii muzycznej Aleksandra Naumowicza Dołżanskiego [Должанский 1964]): martellato (очень отрывисто, отчеканивая), реsante (увесисто), rinforzando (усиливая), strepitoso (шумно), piacevole (привлекательно),

- w tekście recenzji: цуиковое восхищение.

2. Wolfgang Amadeusz Mozart Sonata fortepianowa C-dur KV 330 cz. II (wykonanie Michaił Pletniow)

- tekst nutowy: dolce (очень нежно), adagio (спокойно),

- tekst recenzji: глубинная меланхолия.

3. Edward Grieg Melodia op. 47 (wykonanie Michaił Pletniow)

- tekst nutowy: allegretto, ben tenuto (выдержанно), morendo (замирая),

- tekst recenzji: пронзительный, задумчивый.

4. Robert Schumann Koncert fortepianowy a-moll (cz. III) (wykonanie Michaił Pletniow)

- tekst nutowy: allegro vivace (полный жизни), brillante (блестяще),

- tekst recenzji: восторженный.

5. Robert Schumann I Sonata fortepianowa (wykonanie Jewgienij Kissin)

- tekst nutowy: con fuoco (с огнем), alla burla (цутливо), ma pomoposo (пышно, важно), scherzando (шутливо, весело), passionato (страстныи)), animato (одушевленно),

- tekst recenzji: злая ирония, гротеск.

6. Franz Schubert Sonata fortepianowa B-dur (wykonanie Jewgienij Kissin)

- tekst nutowy: cantabile (певуче) con passione (страстно), slentare (ослаблять),

- tekst recenzji: печальный.

7. Franciszek Liszt Sonet Petrarki nr 104 (Michaił Pletniow)

- tekst nutowy: dolce (очень нежно), dolente (жалобно), languendo (как бы изнемогая), smorzando (приглушая, замирая),

- tekst recenzji: мечтательность.

8. Franciszek Liszt Walc Mefisto (Michaił Pletniow)

- tekst nutowy: con fuoco (с огнем), strepitoso (щумно), dolce (очень нежно) appasionato (страстно), esspresivo (с выражением), amoroso (любовно), quieto (сминно),

- tekst recenzji: демонический.

9. Franciszek Liszt Dolina Obermana (Michaił Pletniow)

- tekst nutowy: tempestoso (бурно), appasionato (страстно), dolcissimo (в высшей степени нежно),

- tekst recenzji: экзальтированныи. 
10. Johannes Brahms I Koncert fortepianowy d-moll (Grigorij Sokołow)

- tekst nutowy: maestoso (Величественно),

- tekst recenzji: мужественно.

11. Johannes Brahms I Koncert fortepianowy d-moll (Hélène Grimaud)

- tekst nutowy: con passione (страстно),

- tekst recenzji: порывистый.

12. Wolfgang Amaduesz Mozart Sonata fortepianowa a-moll KV 310 (Grigorij Sokołow)

- tekstnutowy:calando (затихая), andantecon espressione(свыражением), cantabile (nеbyчe),

- tekst recenzji: грустно, ощущение одиночества, тревога.

Dla pełniejszego obrazu badania, przy porównaniu określeń wykonawczych $w$ tekście nutowym oraz $w$ recenzjach posłużono się słownikiem wyrazów bliskoznacznych [Евгеньева 2001]. Tylko w niektórych przykładach badane jednostki pozostają w relacji synonimicznej, a są to: adagio (спокойно) oraz глубинныи; alla burla (шутливо) / scherzando (шутливо) oraz ирония; slentare (ослаблять) oraz печальный; con passione (страстно) oraz порывисто. W pozostałych przykładach brakuje bezpośrednich związków pomiędzy jednostkami (są jednak pośrednie, np. zarówno tempestoso (бурно), appasionato (страстно) w tekście nutowym, jak і экзальтированный w tekście recenzji pozostają w relacji synonimicznej ze słowem эмоциональный). Trudno się jednak oprzeć wrażeniu, że takie określenia, jak calando - затихая czy con espressione - с выражением mogą oddawać słowa грусть, ощущение одиночества, mpeboza (Sonatę a-moll Mozart napisał po śmierci matki), a wrażenie demoniczności (демонический) określenia: con fuосо - с огнем, dolce - очень нежно, amoroso - ^юбовно i appasionato - страстно. Powyższe rozważania mają jednakże charakter wyłącznie introspekcyjny.

Znaczną liczbę wyników uzyskano dzięki analizie materiału badawczego za pomocą słowników asocjacyjnych [Караулов, Черкасова, Уфимцева, Сорокин, Тарасов 2002; Gawarkiewicz, Pietrzyk, Rodziewicz 2008]. Porównanie związków skojarzeniowych określeń wykonawczych zamieszczonych $\mathrm{w}$ tekście nutowym oraz określeń zamieszczonych $\mathrm{w}$ recenzjach przedstawia się następująco: глубинная (меланхолия) - спокойно (adagio), с огнем (con fuoco) - злой, страстный (passionato), печальный - ослаблять (slentare), nеbуче (w połączeniu: грустная песня poprzez relację synonimiczną słów печальный і грустный); демонический - согнем (con fuосо), страстно, ююбовно (demon - diabet - ogień - namiętność - miłośc); экзальтированный (w znaczeniu przewrażliwiony) - в высшей степени нежно (dolcissimo), экзальтированный (w znaczeniu egzaltowany, gwattowny) - бурно (tempestoso); мужественно величественно (maestoso) - poprzez asocjacje słów majestat i mężczyzna; порывистый - страстно (con passione - z pasją); грустно - певуче (cantabile) 
- poprzez konotację: грустная песня. Wiele spośród analizowanych jednostek nie posiada połączeń skojarzeniowych w wyżej wspomnianych słownikach. Fakt ten ukazuje, jak różnorodne i dalekie od - używając terminologii kognitywnej - jądra danego pojęcia (jakim w tym przypadku jest określenie emocji) skojarzenia może wywoływać muzyka. Należy nadmienić, że powyższe rozważania, będące próbą dla szerszego badania, nie przedstawiają wyczerpującej analizy problemu. Opracowanie tej kwestii wymaga bowiem zastosowania metodologii psychologii kognitywnej. Interesujące rezultaty mogłoby przynieść przeprowadzenie eksperymentu psycholingwistycznego.

\section{Zakończenie}

Niniejszy artykuł miał na celu ukazanie różnorodności środków werbalizacji ludzkich emocji i uczuć, które towarzyszą odbiorcy i wykonawcy muzyki klasycznej. Teksty rosyjskiej krytyki muzycznej posłużyły jako bogate źródło dla badań, ukazujące interesujące spektrum analizowanych jednostek leksykalnych. W pierwszej, strukturalnej części analizy jednostki te pogrupowano według przynależności do części mowy, a następnie poddano badaniom ilościowym. Najbardziej reprezentatywne okazały się przymiotnikowe, rzeczownikowe oraz przymiotnikowo-rzeczownikowe nazwy uczuć. W części drugiej podjęto próbę porównania przykładów werbalizacji emocji $\mathrm{w}$ tekstach krytyki muzycznej z oznaczeniami emocji zawartymi w tekście nutowym. W analizie porównawczej wykorzystano słownik synonimów oraz słowniki asocjacyjne. Uzyskane wstępne wyniki pozwoliły ustalić katalog środków językowych, za których pomocą krytycy werbalizują emocje związane z muzyką klasyczną, otwierając aktualne i interesujące perspektywy badawcze, łączące językoznawstwo z psychologią i muzykologią.

\section{Bibliografia}

Бразговская Е. Е. 2014. Вербализация музыки как межсемиотический перевод, „Критика и семиотика", $\mathrm{nr}$ 1, s. 30-47.

Должанский А. Н. 1964. Краткий музыкальный словарь, Ленинград: Музыка.

Евгеньева А. П. (red.) 2001. Словарь синонимов русского языка, Москва: Астрель.

Иорданская Л. Н. 1970. Попытка лексикографического толкования группы русских глаголов со значением чувства, [w:] Машинный перевод и прикладная лингвистика, вып. 13, Москва: Изд-во Московского педагогического института иностранных языков имени Мориса Тореза, s. 3-26.

Караулов Ю. Н., Черкасова Г. А., Уфимцева Н. В., Сорокин Ю. А., Тарасов Е. Ф. 2002. Русский ассоциативный словаръ, t. I, Москва: Астрель.

Шаховский В. И. 2008. Лингвистическая теория эмоций, Москва: Гнозис. 
Avison Ch. 1775. An Essay on Musical Expression, London: Lockyer Davis.

Biłas-Pleszak E. 2005. Jezyk a muzyka. Lingwistyczne aspekty związków intersemiotycznych, Katowice: Wydawnictwo Uniwersytetu Śląskiego.

Borek M. 1999. Predykaty wyrażajace dyskomfort psychiczny w języku rosyjskim w konfrontacji z jezykiem polskim, Katowice: Wydawnictwo Uniwersytetu Śląskiego.

Fubini E. 1997. Historia estetyki muzycznej, Kraków: Musica Iagellonica.

Gawarkiewicz R., Pietrzyk I., Rodziewicz B. 2008. Polski słownik asocjacyjny, Szczecin: Print Group.

Grabias S. 1997. Jezzyk w zachowaniach społecznych, Lublin: Wydawnictwo Uniwersytetu Marii Curie-Skłodowskiej.

Jęczeń U. 2008. Lingwistyczne sposoby ujmowania zjawisk emocjonalnych, [w:] A. Błachnio, A. Przepiórka (red.). Bliżej emocji II, Lublin: Wydawnictwo KUL.

Langer S. K. 1976. Nowy sens filozofii. Rozważania o symbolach myśli, obrzędu i sztuki, Warszawa: Państwowy Instytut Wydawniczy.

Libanus J. 1519. De Musicae Laudibus Oratio seu adhortatio, Kraków: Jan Helicz, źródło elektroniczne: http:/ / www.dbc.wroc.pl/dlibra/docmetadataid=7006\&from= publication (dostęp 26.09.2017).

Mika B. 2007. Muzyka jako znak (w kontekście analizy paradygmatycznej), Lublin: Polihymnia.

Nowakowska-Kempna I. 1995. Konceptualizacja uczuć w języku polskim, Warszawa: Wyższa Szkoła Pedagogiczna Towarzystwa Wiedzy Powszechnej.

Reiss J. W., Śledziński S. 1960. Mała encyklopedia muzyki, Warszawa: Państwowe Wydawnictwo Naukowe.

Reykowski J. 1992. Procesy emocjonalne, motywacja, osobowość, Warszawa: Wydawnictwo Naukowe PWN.

Rousseau J.-J. 1780-1789. Dictionnaire de musique. Collection complète des oeuvres, vol. 9, Genève: Paul Moultou et du Peyron, źródło elektroniczne: https://www.rous seauonline. ch/pdf/rousseauonline-0068.pdf (dostęp 26.09.2017)

Schweitzer A. 1972. Jan Sebastian Bach, Kraków: Polskie Wydawnictwo Muzyczne.

Wierzbicka A. 1999. Emotions Across Languages and Cultures: Diversity and Universals (Studies in Emotions and Social Interaction), Cambridge: Cambridge University Press. 
